\title{
Ribosome analysis reveals prominent activity of an uncultured member of the class Actinobacteria in grassland soils
}

\author{
Andreas Felske, ${ }^{1}$ Holger Rheims, ${ }^{2}$ Arthur Wolterink, ${ }^{1}$ Erko Stackebrandt ${ }^{2}$ \\ and Antoon D. L. Akkermans ${ }^{1}$
}

\footnotetext{
1 Wageningen Agricultural University, Department of Microbiology, Hesselink van Suchtelenweg 4, $6703 \mathrm{CT}$ Wageningen, The Netherlands

2 DSMZ - Deutsche Sammlung von Mikroorganismen und Zellkulturen $\mathrm{GmbH}$, Mascheroder Weg 1b, 38124 Braunschweig, Germany
}

\author{
Author for correspondence: Andreas Felske. Tel: +31 317 484250. Fax: +31317483829. \\ e-mail: Andreas.Felske@algemeen.micr.wau.nl
}

Keywords: $16 \mathrm{~S}$ rDNA library, Actinobacteria, temperature-gradient gel electrophoresis (TGGE), ribosome extraction from soil, V6 probe

\section{INTRODUCTION}

Over the last few years, molecular ecological studies on mainly terrestrial environments (Liesack \& Stackebrandt, 1992a, b; Stackebrandt et al., 1993; Rheims et al., 1996a, b) have indicated the existence of two monophyletic groups of uncultured bacteria from the class Actinobacteria (Stackebrandt et al., 1997). As judged from the analysis of PCR-amplified 16S rDNA these sequences showed only rather remote similarities to sequences of cultured actinobacteria. The relevant clones were obtained from an Australian forested soil taken from the Mount Coot-tha region in Brisbane,

Abbreviation: TGGE, temperature-gradient gel electrophoresis.

The EMBL accession number for the sequence of DA079 reported in this paper is $Y 11555$.
Queensland (Liesack \& Stackebrandt, 1992a, b; Stackebrandt et al., 1993), a peat bog sample from Germany (Rheims et al., 1996a, b), geothermally heated soil from New Zealand (Rainey et al., 1993) and a soil sample from Finland (Saano et al., 1995). Also, short 16S rDNA clone sequences from a paddy field (Maidak et al., 1994), a soybean field (Ueda et al., 1995) and a marine environment (Fuhrman et al., 1993) were demonstrated to cluster with these actinobacterial sequences. Thus it has been concluded that this group of uncultured organisms might contribute to ecologically important processes (Rheims et al., 1996b).

The presence of rDNA sequences in a clone library proves neither activity nor abundance of the microorganism from which the DNA is represented in the library. Previous investigations already indicated that a large fraction of environmental microbial communities 
is in a stage of low activity or resting (Bakken \& Olsen, 1987; Roszak et al., 1984). DNA obtained from environmental samples could thus originate from such dormant cells, from dead cells (Josephson et al., 1993), or even from free DNA. Adsorption of DNA at mineral surfaces, especially in soils, could harbour more or less intact nucleic acids a long time after lysis of the source organism (Lorenz \& Wackernagel, 1987). Our strategy to obtain information about the presence of metabolically active bacteria in the environment focuses on the analysis of $16 \mathrm{~S}$ rRNA from isolated ribosomes. As the ribosome per cell ratio is roughly proportional to growth rate of bacteria (Wagner, 1994), rRNA is regarded as an indicator of total bacterial activity.

Here we report on the finding of a novel sequence of one of the actinobacterial lineages from the Drentse A rDNA clone library (A. Felske, A. Wolterink, R. van Lis \& A. D. L. Akkermans, unpublished results). The cloned sequence DA079 was investigated for its significance in the environmental $16 \mathrm{~S} \mathrm{rDNA}$ population and $16 \mathrm{~S} \mathrm{rRN}$ fractions of ribosomes that were isolated from the same site (Drentse A agricultural test area, The Netherlands). After direct ribosome isolation from soil samples (Felske et al., 1996), rRNA was purified and used for RT-PCR with bacteria-specific primers. This partial 16S rRNA amplicon, representing the complex sequence population of the soil, was sequence-specifically separated by temperature-gradient gel electrophoresis (TGGE; Rosenbaum \& Riesner, 1987). The resulting fingerprint was screened for the cloned sequence DA079 by amplifying the plasmid DNA with the same primers as those used for soil rRNA. Running this product next to the rRNA fingerprint indicated possible matches. Subsequent electrophoretic Southern blotting and hybridization with a clone-specific probe was applied to confirm the match.

\section{METHODS}

Collection of soil samples. Peaty, acid grasslands of the Drentse A agricultural research fields next to the Anlooër Diepje River, the Netherlands $\left(06^{\circ} 41^{\prime} \mathrm{E}, 53^{\circ} 03^{\prime} \mathrm{N}\right)$, were the sites of sample collection. A total of 120 surface samples ( $<10 \mathrm{~cm}$ depth) were taken on three different testfields during March 1996. Another 240 surface samples were taken on the same and additional three testfields in October 1996. Six different testfields (A, B, C, F, K and O) along the Anlooër Diepje River were investigated. Distances between the relevant testfields were several hundred metres, with a maximum of $1.5 \mathrm{~km}$ between testfields $\mathrm{F}$ and $\mathrm{K}$. On each testfield, 40 soil cores of about $50 \mathrm{~g}$ were taken with a drill $(0-10 \mathrm{~cm}$ depth) and transferred into sterile sample bags. The 40 samples of each testfield were pooled to four samples by sieving and mixing 10 single samples ( $5 \mathrm{~g}$ input each). Details of the soil properties were published by Stienstra et al. (1994).

Isolation, amplification, cloning and sequencing of 16S rDNA sequences. Total DNA was isolated from Drentse A soil samples by a parallel pathway during ribosome isolation (Felske et al., 1996). Amplification of 16S rDNA sequences was performed with a GeneAmp PCR System 2400 thermocycler (Perkin Elmer Cetus), using 35 cycles of $94^{\circ} \mathrm{C}$ for $10 \mathrm{~s}$, $54{ }^{\circ} \mathrm{C}$ for $20 \mathrm{~s}$ and $68^{\circ} \mathrm{C}$ for $2 \mathrm{~min}$. The PCR reactions $(100 \mu \mathrm{l})$ contained $10 \mathrm{mM}$ Tris $/ \mathrm{HCl}(\mathrm{pH} 8.3), 50 \mathrm{mM} \mathrm{KCl}, 3 \mathrm{mM}$
$\mathrm{MgCl}_{2}, 0.05 \%$ detergent W-1 (LifeTechnologies), $150 \mu \mathrm{M}$ each of dATP, dCTP, dGTP and dTTP, 100 pmol primers $8 \mathrm{f}$ and $1512 \mathrm{r}$ (as below), 2.5 U Taq DNA polymerase (LifeTechnologies), and $1 \mu$ l template DNA. Amplification products were confirmed by $1.4 \%$ agarose gel electrophoresis and then separated from primers and dNTPs on a low-meltingpoint agarose gel. Subsequently they were cloned in pGEM-T linear plasmid vector and Escherichia coli JM109 competent cells according to the manufacturer's instructions (Promega). Isolated and purified plasmids (Wizard 373 DNA purification system; Promega) were sequenced using a Sequenase (T7)terminator dsDNA sequencing kit (Pharmacia) on a Li-Cor Sequencer $4000 \mathrm{~L}$.

Isolation of ribosomes and amplification of 16S rRNA. Ribosomes were isolated from Drentse A soil samples $(1 \mathrm{~g}$ input) as previously described (Felske et al., 1996). RT-PCR was performed with the rTth DNA Polymerase kit from Perkin Elmer Cetus. Reverse transcription reactions $(10 \mu \mathrm{l})$ contained $10 \mathrm{mM}$ Tris $/ \mathrm{HCl}(\mathrm{pH} \mathrm{8.3)}, 90 \mathrm{mM} \mathrm{KCl}, 1 \mathrm{mM}$ $\mathrm{MnCl}_{2}, 200 \mu \mathrm{M}$ each of dATP, dCTP, dGTP and dTTP, $750 \mathrm{nM}$ primer L1401 (as below), 2.5 U rTth DNA polymerase and $1 \mu \mathrm{l}$ template RNA. After incubation for $15 \mathrm{~min}$ at $68^{\circ} \mathrm{C}$ (reverse transcription), $40 \mu \mathrm{l} \mathrm{PCR}$ additive containing $10 \mathrm{mM}$ Tris/ $\mathrm{HCl}$ (pH 8.3), $100 \mathrm{mM} \mathrm{KCl,} 0.75 \mathrm{mM}$ EGTA, 0.05\% (v/v) Tween $20,3.75 \mathrm{mM} \mathrm{MgCl}_{2}, 50 \mu \mathrm{M}$ each of dATP, dCTP, dGTP, and dTTP, $190 \mathrm{nM}$ primer U968/GC (as below) were added. Amplification was performed in a GeneAmp PCR System 2400 thermocycler, using 35 cycles of $94^{\circ} \mathrm{C}$ for $10 \mathrm{~s}$, $56^{\circ} \mathrm{C}$ for $20 \mathrm{~s}$ and $68^{\circ} \mathrm{C}$ for $40 \mathrm{~s}$. The correct size of amplification products was checked by electrophoresis on a $1.4 \%$ agarose gel.

Partial 165 rDNA amplification of clone DA079 for TGGE. A single DA079 clone colony (identified by sequence analysis) was taken up with a sterile toothpick and transferred to a $1.5 \mathrm{ml}$ microcentrifuge tube containing $50 \mu \mathrm{l} \mathrm{TE} \mathrm{buffer.} \mathrm{The}$ tube was heated for $15 \mathrm{~min}$ at $95^{\circ} \mathrm{C}$ and then chilled on ice. A TGGE-suitable 16S rDNA amplicon was generated with a GeneAmp PCR System 2400 thermocycler, using 25 cycles of $94^{\circ} \mathrm{C}$ for $10 \mathrm{~s}, 56^{\circ} \mathrm{C}$ for $20 \mathrm{~s}$ and $68^{\circ} \mathrm{C}$ for $40 \mathrm{~s}$. The PCR reactions $(20 \mu \mathrm{l})$ contained $10 \mathrm{mM}$ Tris $/ \mathrm{HCl}(\mathrm{pH} 8 \cdot 3), 50 \mathrm{mM}$ $\mathrm{KCl}, 3 \mathrm{mM} \mathrm{MgCl}, 50 \mu \mathrm{M}$ each of dATP, dCTP, dGTP, and dTTP, 100 pmol primers U968/GC and L1401 (as below), $0.5 \mathrm{U}$ Taq DNA polymerase and $1 \mu \mathrm{l}$ DA079 cell lysate. Dilution series of the PCR product $(2,1,0.5$ and $0.25 \mu l$ per lane) were used for subsequent TGGE and electrophoretic Southern blotting.

Preparation of the clone-specific probe V6-DA079. A probe for the clone DA079 was generated by amplification of the highly variable V6 region of the $16 \mathrm{~S}$ rDNA (Heuer \& Smalla, 1997) with a GeneAmp PCR System 2400 thermocycler, using 30 cycles of $94^{\circ} \mathrm{C}$ for $10 \mathrm{~s}, 46^{\circ} \mathrm{C}$ for $20 \mathrm{~s}$ and $68^{\circ} \mathrm{C}$ for $10 \mathrm{~s}$. The PCR reaction $(100 \mu \mathrm{l})$ contained $10 \mathrm{mM}$ Tris $/ \mathrm{HCl}$ (pH 8.3), $50 \mathrm{mM} \mathrm{KCl}, 3 \mathrm{mM} \mathrm{MgCl}_{2}, 25 \mu \mathrm{M}$ each of dATP, dCTP, dGTP, and dTTP, $200 \mathrm{pmol}$ primers V971 and R1057 (as below), 2.5 U Taq DNA polymerase and $1 \mu$ l DA079 cell lysate. Resulting PCR products were purified and concentrated by ethanol precipitation. The precipitated DNA was resolved in $50 \mu \mathrm{l}$ nanopure water and then $5^{\prime}$-labelled using phage T4 polynucleotide kinase (Promega) and $3.7 \mathrm{~Bq}$ of $\left[\gamma^{32} \mathrm{P}\right] \mathrm{ATP}$ ( $370 \mathrm{MBq} \mathrm{ml} l^{-1}$; Amersham Buchler) in a 30 min reaction at $37^{\circ} \mathrm{C}$.

TGGE, electrophoretic Southern blot and hybridization. The Diagen TGGE system was used for sequence-specific separation of PCR products. The temperature gradient was optimized to $9^{\circ} \mathrm{C}$ difference for improved resolution. Electro- 
phoresis was performed with a $0.8 \mathrm{~mm}$ polyacrylamide gel $(6 \%, \mathrm{w} / \mathrm{v}$, acrylamide; $0 \cdot 1 \%, \mathrm{w} / \mathrm{v}$, bis-acrylamide; $8 \mathrm{M}$ urea; $20 \%, v / v$, formamide; $2 \%, v / v$, glycerol) with $1 \times$ TA buffer ( $40 \mathrm{mM}$ Tris-acetate, $\mathrm{pH} \mathrm{8.0)}$ at a fixed current of $9 \mathrm{~mA}$ (about $120 \mathrm{~V}$ ) for $16 \mathrm{~h}$. A temperature gradient from 37 to $46^{\circ} \mathrm{C}$ was established in the direction of electrophoresis. Samples for RT-PCR of soil rRNA and PCR of plasmid DNA were applied twice in symmetrical order.

After electrophoresis one-half of the gel was used for silver staining (Engelen et al., 1995), the other half for Southern blotting. This half was shaken for $15 \mathrm{~min}$ in $0.5 \times \mathrm{TBE}$ buffer (Sambrook et al., 1989). Two pieces of gel-sized Whatman filter paper and one sheet of nylon membrane (Hybond-N+; Amersham) were treated in the same way. One filter paper, the membrane, the gel and finally the other filter paper were placed above each other into a TransBlot SD Electrophoretic Transfer Cell (Bio-Rad). After closing the transfer cell a current of $400 \mathrm{~mA}$ was applied for $1 \mathrm{~h}$. After this electrophoretic blot the membrane was briefly washed in $0.5 \times \mathrm{TBE}$ and placed on top of another Whatman filter paper (presoaked with $0.4 \mathrm{M} \mathrm{NaOH}$ ) for $10 \mathrm{~min}$. After shaking the membrane for $10 \mathrm{~min}$ in $2 \times$ SSC (Sambrook et al., 1989), the DNA was immobilized by baking at $120^{\circ} \mathrm{C}$ for $30 \mathrm{~min}$. Prehybridization $\left(1 \mathrm{~h}\right.$ at $\left.56^{\circ} \mathrm{C}\right)$ and hybridization $(16 \mathrm{~h}$ at $56^{\circ} \mathrm{C}$ ) were performed in $5 \times$ SSC with $2 \%(\mathrm{w} / \mathrm{v}$ ) blocking reagent (Boehringer), $0.1 \% \mathrm{~N}$-lauroylsarkosine, $0.02 \% \mathrm{SDS}$ and $20 \%(\mathrm{v} / \mathrm{v})$ formamide. For hybridization, $10 \mu \mathrm{l}$ labelled probe V6-DA079 were added. Subsequent stringent washing steps were twice for $5 \mathrm{~min}$ in $2 \times$ SSC with $0.1 \%$ SDS and twice for $15 \mathrm{~min}$ in $0.1 \times \mathrm{SSC}$ with $0.1 \% \mathrm{SDS}$ on a shaker at room temperature. A detection screen (Molecular Dynamics) was incubated with the hybridized membrane and the probe signals were detected with a Phosphor Imager SF (Molecular Dynamics). Quantification was performed with image analysis software ImageMaster 1D Elite version 2.0 (Pharmacia).

Oligonucleotides. All oligonucleotides used in this study were specific for bacterial $16 \mathrm{~S} \mathrm{rRNA}$. The numbers in the primer names indicate the position of the $5^{\prime}$ nucleotide in the $16 \mathrm{~S}$ rRNA of $E$. coli (Brosius et al., 1978). The sequence for primer U968/GC is $5^{\prime}$-(GC clamp)-AAC GCG AAG AAC CTT AC$3^{\prime}$, and for primer L1401 it is 5'-CGG TGT GTA CAA GAC CC-3'. These 17 mers are specific for highly conserved $16 \mathrm{~S}$ rRNA regions from bacteria (Nübel et al., 1996). The sequence of the GC clamp, linked to the $5^{\prime}$ terminus of the PCRamplified product is $5^{\prime}$-CGC CCG GGG CGC GCC CCG GGC GGG GCG GGG GCA CGG GGG G-3'. This $40 \mathrm{mer}$ is useful for accurate separation of PCR products in the gradient gel electrophoresis (Muyzer et al., 1993).

The primers used for generating the clone library are were $8 \mathrm{f}$, 5'-CAC GGA TCC AGA CTT TGA T(C/T)(A/C) TGG CTC AG-3', and 1512r, 5'-GTG AAG CTT ACG G(C/T)T AGC TTG TTA CGA CTT-3'. Both are specific for highly conserved 16S rRNA regions of bacteria (taken and modified from Weisburg et al., 1991).

Probe V6-DA079 was amplified with primers V971, 5'-GCG AAG AAC CTT ACC-3', and R1057, 5'-CAT GCA GCA CCT GT-3'; both are specific for highly conserved $16 \mathrm{~S}$ rRNA regions from bacteria (Hartung, 1996).

Phylogenetic analysis for clone DA079. The 16S rDNA sequence of clone DA079 was transferred to the alignment editor AE2 (Maidak et al., 1994) and compared to the DSMZ $16 \mathrm{~S}$ rDNA database of Actinobacteria. The sequence of DA079 was then compared to the most closely related members of uncultured peat organisms of groups II and III and their closest cultivated relatives. Sequences of clones from other environments could not be shown within the same tree (except clone MC58), as they do not have enough sequence information or overlap with the other clone sequences. For the construction of a phylogenetic tree, sequences from other more remotely related organisms were also included in the comparison.

The similarity values for these sequences were transformed into phylogenetic distance values that compensate for multiple substitutions at any given site in the sequence (Jukes $\&$ Cantor, 1969). The phylogenetic dendrogram was constructed with the neighbour-joining method included in the PHYLIP package (Felsenstein, 1993).

\section{RESULTS AND DISCUSSION}

\section{Detection of clone DA079 rDNA and related environmental sequences in soils}

Clone DA079 originates from a Drentse A 16S rDNA clone library, comprising 165 positive clones (A. Felske, A.Wolterink, R. van Lis \& A. D. L. Akkermans, unpublished results). Two other clones were identical in sequence, so finally three of 165 clones represented this DA079 sequence. Some closely related German peat clones (designated TM clones) were previously found to have relatives in geographically widely separated soil environments, i.e. Australia, Finland, Japan, New Zealand, and in the Atlantic and Pacific oceans (summarized by Rheims et al., 1996b). With the detection of the uncultured organism DA079 in Drentse A grassland soils another example for the wide distribution of this novel group of uncultured actinobacteria in different soil types is given.

In detail, clone DA079 is a member of peat clone group II (as defined by Rheims et al., 1996b), showing a similarity of $95.3 \%$ to clone TM208 (Fig. 1). No close relationship exists between the peat clone group II (including clone DA079) and the nearest cultured relative, Acidimicrobium ferrooxidans (Clark \& Norris, 1996). According to the current taxonomic structure of the class Actinobacteria (Stackebrandt et al., 1997), even a relationship at family level seems unlikely.

\section{Quantification of sequences in clone libraries}

To draw a conclusion on the importance of these organisms, as detected by analysis of amplification products, the following factors should be considered.

Deduction of the number of organisms characterized by a unique $16 \mathrm{~S}$ rDNA sequence in the community from the number of sequences in a $16 \mathrm{~S}$ rDNA library is difficult. As most $16 \mathrm{~S}$ rDNA sequences appear only once during sequence analysis of clones (Weller et al., 1991; Borneman et al., 1996), the question is raised whether this reflects the real abundance or whether these unique sequences were randomly recovered from a low-abundance background?

One may imagine a model in which $50 \%$ of all the $16 \mathrm{~S}$ rDNA within a native bacterial community originates from a few dozen dominant species. The other $50 \%$ consists of thousands of rare sequences occurring with 


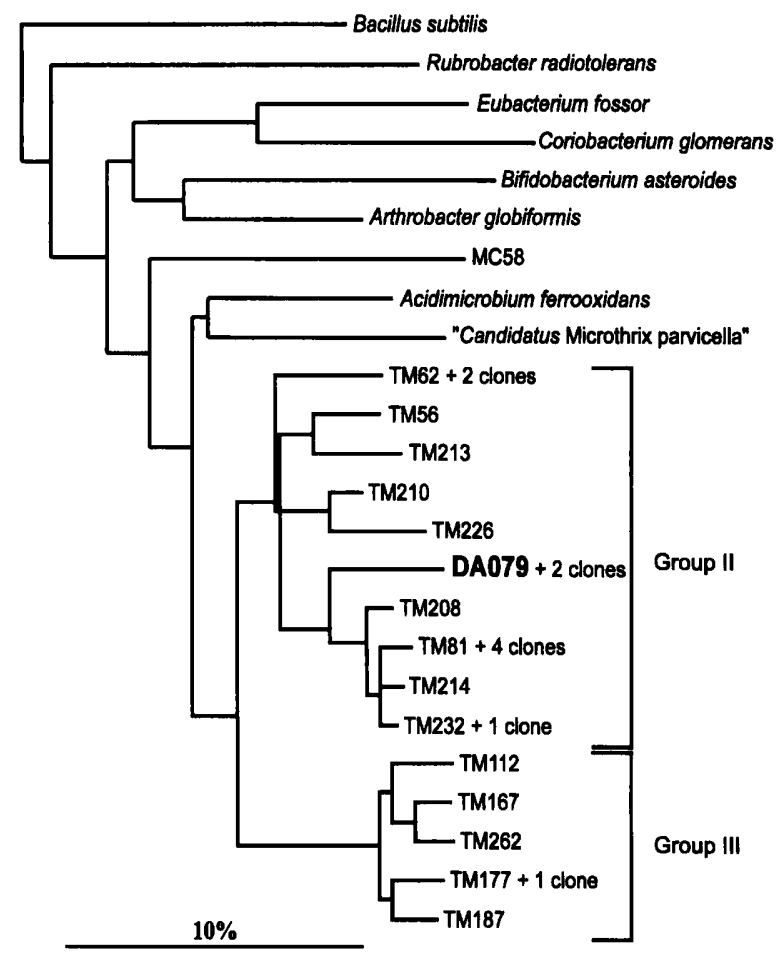

Fig. 1. Dendrogram showing phylogenetic positions of 165 rDNA related groups II and III and the clone DA079 within the Actinobacteria. The sequence of Bacillus subtilis served as an outgroup sequence. The analysis is based on about $11005^{\prime} \mathrm{nt}$ of the 16S rDNA sequence (limited by the length of the sequence of clone MC58). The bar represents $10 \mathrm{nt}$ substitutions per $100 \mathrm{nt}$.

a very low mean abundance each. This model is not unreasonable as the presence of thousands of different bacterial species can be expected to occur in a single soil sample (Torsvik et al., 1990). Extraction of DNA and subsequent PCR amplification with universal bacterial primers yields a $16 \mathrm{~S}$ rDNA amplicon of a very complex sequence composition, optimally reflecting the native composition. In the subsequent steps of ligation and transformation, the selection of sequences is random. Hence rare sequences have a realistic chance of appearing in a successfully cloned insert. In our model, one-half of all clones will represent the few dominant species, while the other half is composed of randomly selected members of a low-abundance background. The higher the microbial diversity, the more likely is the appearance of such randomly selected rare sequences. Thus the normally limited size of environmental clone libraries (a few hundred clones) has the danger of overestimating unique clones. Multiple detection of identical clone sequences within one clone library, on the other hand, might indeed indicate abundance in the original population. In this study three identical $16 \mathrm{~S}$ rDNA sequences of the type DA079 were identified within the Drentse A library of 165 clones.

In contrast to the uncertain meaning of sequence quantities in clone libraries, the semi-quantitative as-



Fig. 2. Amplicon fingerprints on silver-stained TGGE gels. RTPCR products from ribosomes and a partial 165 rDNA PCR product from genomic DNA from the same probing site, obtained with the corresponding set of primers, each show bands of equal position, matching with the DA079 signal as indicated. Fingerprints represent two of four pooled samples each from Drentse A sites A, F and K. 'SS' indicates the position and size of the single-stranded CDNArDNA fraction.

sessment of PCR amplicons in TGGE fingerprints is only based on staining intensity. A silver-stained TGGE gel would show a background of thousands of different sequences as a faint background smear, somewhere between invisibility and extremely faint bands. Hence estimation of sequence abundance in genetic material isolated from the environment is more likely to be representative by application of the TGGE approach.

\section{Detection of sequence DA079 by TGGE in total rRNA and rDNA from soil}

Direct ribosome isolation yielded purified $\mathrm{rRNA}[1 \cdot 5 \pm$

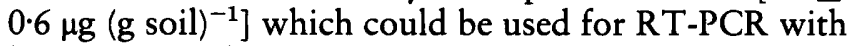
bacteria-specific primers. Ribosome isolation and subsequent RT-PCR were reproducible as demonstrated by TGGE. Partial sequences of the 16S rRNA were reversibly transcribed into cDNA, amplified by PCR and the products separated by high-resolution TGGE. The TGGE fingerprint (Fig. 2) reflects the diversity of dominant $r$ RNA sequences of pooled soils from different sampling sites. Fingerprints from the same testfield were highly reproducible. Pooled samples from the same testfield, as presented in this study, appeared to be identical (Fig. 2). This indicates a high spatial constancy of the dominant bacteria in these grassland soils.

To determine whether one of the major bands could be affiliated to $16 \mathrm{~S}$ rDNA of clone DA079, its plasmid insert was amplified with TGGE primers U968/GC and L1401. The migration distance of the fragment obtained from 


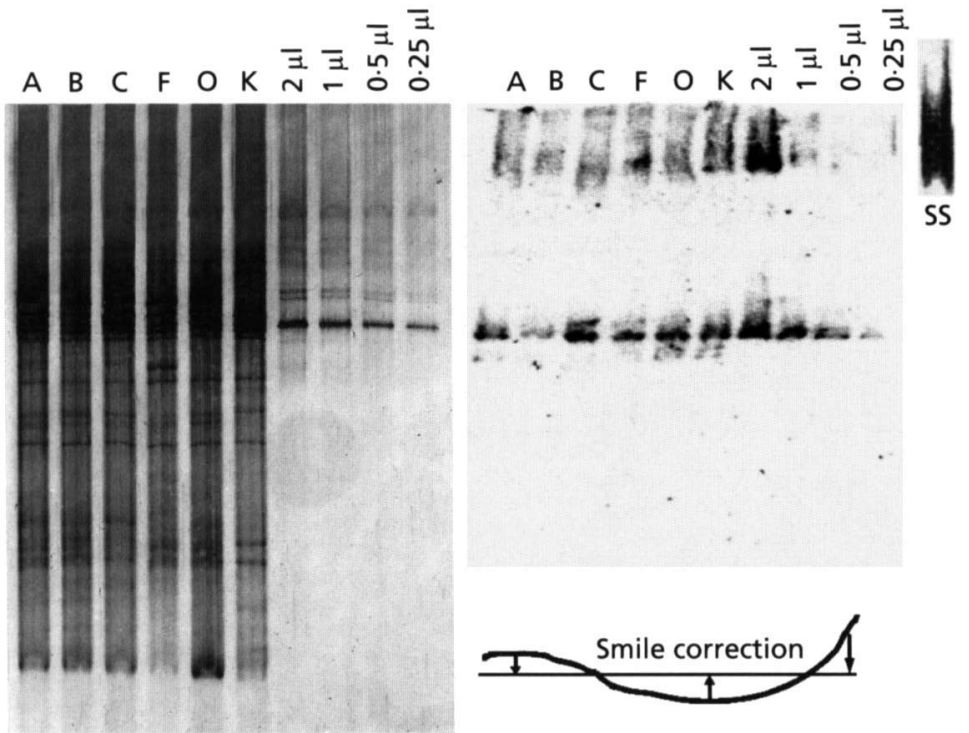

\begin{abstract}
Fig. 3. Comparison between a silver-stained TGGE gel (left-hand side) and the second half of the same gel after an electrophoretic Southern blot and hybridization with the V6-DA079 probe (right-hand side). The DNA samples were loaded onto corresponding positions. RT-PCR products from ribosomes of the native bacterial community represent pooled samples from Drentse A sites A, B, C, $F, K$ and $O$. Next to this, dilution series of the DA079 PCR product $(2,1,0.5$ and $0.25 \mu l)$ were applied. On top of the gel lanes, single-stranded DNA appears (position and size marked ' $S S^{\prime}$ '). At this position the V6DA079 probe gives hybridization signals as well. The 'smile correction' bar indicates an image correction carried out to compensate for distortions of the blot signals.
\end{abstract}

the DA079 clone was identical to one of the strongest bands obtained from amplified cDNA. Here the definition of total activity allows two scenarios for abundance and state of the bacterial cells: this species counts for high total activity within the community by only low activity per cell, but extraordinarily high cell number; or this species could show an extraordinarily high activity per cell, but only low cell number within the community. The TGGE fingerprints obtained from amplified genomic rDNA from soil (Fig. 2) point more to the first scenario. They indicate that sequence DA079 is not only one of the most abundant $16 \mathrm{~S}$ rRNA but also $16 \mathrm{~S}$ rDNA sequences. The relative abundance of DA079 in the rDNA fingerprints appears comparable to the $16 \mathrm{~S}$ rRNA in the ribosomal RT-PCR fingerprints. Thus it seems likely that the prominent ribosome number from this species is caused more by the high number of active cells rather than by extraoordinarily high activity per cell. The high reproducibility of the TGGE fingerprints further indicates a homogeneous distribution of this activity.

\section{Confirmation of sequence DA079 by V6 probing}

As even the high resolution of TGGE does not absolutely exclude the possibility that two different $16 \mathrm{~S}$ cDNA sequences might migrate to exactly the same position in the gel, the authenticity of the two corresponding bands needed to be verified. A TGGE gel was symmetrically loaded, each half containing cDNA samples prepared from ribosomes of different sampling sites and dilutions of the PCR products obtained from $16 \mathrm{~S}$ rDNA of clone DA079. One-half of the gel was stained with silver, while the material of the second half was blotted onto a membrane and hybridized with a DA079-specific, radioactively labelled probe (Fig. 3). Comparison of the signals of both approaches allows the conclusion that $97 \pm 5 \%$ of the silver-stained fingerprint band was indeed composed of the DA079 16S rDNA fragment (Table 1).
The $95 \mathrm{nt}$ probe used in Southern hybridization was derived from the $16 \mathrm{~S}$ rDNA insert of clone DA079. Comparison of the probe sequence with the homologous region of clone sequences from highly related actinobacteria detected in a peat bog (Rheims et al., 1996b) gave highest similarity values above $98 \%$ (data not shown). The question is raised whether the hybridization results indicate the presence of sequence DA079 in the ribosome fraction and rDNA clone library to the exclusion of other highly related actinobacterial sequences, as found in the peat bog clone library. Most likely, such sequences would migrate to different positions in the TGGE gel. It must be assumed that sequence DA079 is the only prominent member of this group in the ribosome fraction. Other highly related actinobacterial sequences might also be present in the minority population, but they are not detectable in the TGGE fingerprints.

\section{Conclusions}

This study suggests that the cloned sequence DA079 originated from one of the most active bacterial species in Drentse A grassland soils. The strength of the DA079 band in the TGGE fingerprints and the hybridization signal demonstrated a prominent abundance of this sequence within the ribosomal $16 \mathrm{~S}$ rRNA and genomic $16 \mathrm{~S}$ rDNA fractions from soil. Hence, it can be concluded that the as-yet-uncultured actinobacteria are a potentially important part of the native bacterial community in Drentse A grassland soil. This leads to the speculation that their role is similar in the other environments where their presence had been described previously. The $16 \mathrm{~S}$ rDNA clone libraries generated in the past provided first indications of the enormous degree of prokaryotic diversity by revealing hitherto unknown sequences of unidentified organisms. After analysis of the cloned sequences we can now turn back to the environment to reveal the ecologically relevant 
Table 1. Pixel volume quantification ratios for silver staining vs hybridization signals, respectively, soil fingerprint vs DA079

\begin{tabular}{|c|c|c|c|c|}
\hline \multirow[t]{2}{*}{ Lane } & \multicolumn{2}{|c|}{ Image pixel volume for: } & \multirow{2}{*}{$\begin{array}{c}\text { Ratio A/B } \\
\quad(=\mathrm{C})\end{array}$} & \multirow{2}{*}{$\begin{array}{c}\text { DA079 signal/soil } \\
\text { fingerprint ratio } \\
(1.96 / \mathrm{C})\end{array}$} \\
\hline & Silver staining (A) & Hybridization (B) & & \\
\hline A & $114 \cdot 12$ & $57 \cdot 74$ & 1.98 & 0.99 \\
\hline B & $55 \cdot 54$ & $22 \cdot 59$ & $2 \cdot 46$ & $0 \cdot 80$ \\
\hline $\mathrm{C}$ & 116.92 & 59.65 & 1.96 & $1 \cdot 00$ \\
\hline $\mathrm{F}$ & $86 \cdot 92$ & $40 \cdot 65$ & $2 \cdot 14$ & 0.92 \\
\hline $\mathrm{K}$ & $93 \cdot 15$ & $51 \cdot 25$ & $1 \cdot 70$ & $1 \cdot 15$ \\
\hline $\mathrm{O}$ & $114 \cdot 32$ & 54.67 & $2 \cdot 09$ & 0.94 \\
\hline \multicolumn{3}{|c|}{ Mean of all soil samples (SD) } & $2 \cdot 06(11)$ & $0.97(5)$ \\
\hline $2 \mu l$ & $135 \cdot 44$ & $77 \cdot 45$ & 1.75 & - \\
\hline $1 \mu \mathrm{l}$ & $99 \cdot 05$ & $50 \cdot 83$ & $1 \cdot 97$ & - \\
\hline $0.5 \mu l$ & $44 \cdot 24$ & $24 \cdot 04$ & $1 \cdot 84$ & - \\
\hline $0 \cdot 25 \mu \mathrm{l}$ & $20 \cdot 35$ & $9 \cdot 00$ & $2 \cdot 26$ & - \\
\hline \multicolumn{3}{|c|}{ Mean of all DA079 samples (SD) } & $1.96(10)$ & - \\
\hline
\end{tabular}

organisms. Application of ribosome isolation, subsequent RT-PCR and separation of amplicons by TGGE, in combination with taxon-specific probing, leads to the identification of the metabolically dominant portion of the community. This allows us to more specifically discuss the composition of environmental microbial communities.

\section{ACKNOWLEDGEMENTS}

This work was supported by a grant from the European Community project 'High Resolution Automated Microbial Identification' (EC-HRAMI project BIO2-CT94-3098). H.R. was supported by a grant from the German research council (DFG-Sta184/13-1). We want to thank the Dutch State Forestry Commission, who allowed us access to the nature reserve.

\section{REFERENCES}

Bakken, L. R. \& Olsen, R. A. (1987). The relationship between cell size and viability of soil bacteria. Microb Ecol 13, 103-114.

Borneman, J., Skroch, P. W., O'Sullivan, K. M., Palus, J. A., Rumjanek, N. G., Jansen, J. L., Nienhuis, J. \& Triplett, E. W. (1996). Molecular microbial diversity of an agricultural soil in Wisconsin. Appl Environ Microbiol 62, 1935-1943.

Brosius, J., Palmer, M. L., Kennedy, P. J. \& Noller, H. F. (1978). Complete nucleotide sequence of a $16 \mathrm{~S}$ ribosomal RNA gene from Escherichia coli. Proc Natl Acad Sci USA 75, 4801-4805.

Clark, D. A. \& Norris, P. R. (1996). Acidimicrobium ferrooxidans gen. nov., sp. nov.: mixed-culture ferrous iron oxidation with Sulfobacillus species. Microbiology 142, 785-790.

Engelen, B., Heuer, H., Felske, A., Nubel, U., Smalla, K. \& Backhaus, H. (1995). Protocols for the TGGE. In Abstracts for the Workshop on Application of DGGE and TGGE in Microbial Ecology 1995. BBA for Agriculture And Forestry, Braunschweig. Felsenstein, J. (1993). PHYLIP (Phylogeny Inference Package) version 3.5.1. Seattle: Department of Genetics, University of Washington.

Felske, A., Engelen, B., Nubel, U. \& Backhaus, H. (1996). Direct ribosome isolation from soil to extract bacterial rRNA for community analysis. Appl Environ Microbiol 62, 4162-4167.

Fuhrman, J. A., McCallum, K. \& Davis, A. A. (1993). Phylogenetic diversity of subsurface marine microbial communities from the Atlantic and Pacific oceans. AppI Environ Microbiol 59, 1294 1302.

Hartung, K. (1996). Entwicklung von Sonden zur Interpretation von TGGE-Gelen für die Analyse mikrobieller Gemeinschaften. Diploma thesis, Fachhochschule Lippe.

Heuer, H. \& Smalla, K. (1997). Application of denaturing gradient gel electrophoresis (DGGE) and temperature gradient gel electrophoresis (TGGE) for studying soil microbial communities. In Modern Soil Microbiology, pp. 353-373. Edited by J. D. van Elsas, E. M. H. Wellington \& J. T. Trevors. New York: Marcel Dekker.

Josephson, K. L., Gerba, C. P. \& Pepper, T. L. (1993). Polymerase chain reaction of nonviable bacterial pathogens. Appl Environ Microbiol 59, 3513-3515.

Jukes, T. H. \& Cantor, C. R. (1969). Evolution of protein molecules. In Mammalian Protein Metabolism, pp. 21-132. Edited by H. N. Munro. New York: Academic Press.

Liesack, W. \& Stackebrandt, E. (1992a). Occurrence of novel groups of the domain Bacteria as revealed by analysis of genetic material isolated from an Australian terrestrial environment. $J$ Bacteriol 174, 5072-5078.

Liesack, W. \& Stackebrandt, E. (1992b). Unculturable microbes detected by molecular sequences and probes. Biodivers Conserv 1 , 250-262.

Lorenz, M. G. \& Wackernagel, W. (1987). Adsorption of DNA to sand and variable degradation rates of adsorbed DNA. Appl Environ Microbiol 53, 2948-2952.

Maidak, B. L., Larsen, N., McCaughey, M. J., Overbeck, R., Olsen, G. J., Fogel, K., Blandy, J. \& Woese, C. R. (1994). The ribosomal database project. Nucleic Acids Res 22, 3483-3487.

Muyzer, G., De Waal, E. C. \& Uitterlinden, A. G. (1993). Profiling of complex microbial populations by denaturing gradient gel electrophoresis analysis of polymerase chain reaction-amplified genes coding for 16S rRNA. Appl Environ Microbiol 59, 695-700. Nubel, U., Engelen, B., Felske, A., Snaidr, J., Wieshuber, A., Amann, R. I., Ludwig, W. \& Backhaus, H. (1996). Sequence 
heterogeneities of genes encoding 16S rRNAs in Paenibacillus polymyxa detected by temperature gradient gel electrophoresis. J Bacteriol 178, 5636-5643.

Rainey, F. A., Ward, N. L. \& Stackebrandt, E. (1993). Molecular ecology study of a New Zealand acidothermal soil. In Thermophiles '93, Hamilton, New Zealand, abstract A7. Hamilton: University of Waikato.

Rheims, H., Rainey, F. A. \& Stackebrandt, E. (1996a). A molecular approach to search for diversity among bacteria in the environment. J Ind Microbiol 17, 159-169.

Rheims, H., Spröer, C., Rainey, F. A. \& Stackebrandt, E. (1996b). Molecular biological evidence for the occurrence of uncultured members of the actinomycete line of descent in different environments and geographical locations. Microbiology 142, 2863-2870.

Rosenbaum, V. \& Riesner, D. (1987). Temperature-gradient gel electrophoresis - thermodynamic analysis of nucleic acids and proteins in purified form and in cellular extracts. Biophys Chem 26, 235-246.

Roszak, D. B., Grimes, D. J. \& Colwell, R. R. (1984). Viable but nonrecoverable stage of Salmonella enteritidis in aquatic systems. Can J Microbiol 30, 334-338.

Saano, A., Lindström, K. \& Van Elsas, J. D. (1995). Eubacterial diversity in Finnish forest soil. In 7th International Symposium on Microbial Ecology, Santos, Brazil, abstract P1-3.9. Santos: Brazilian Society for Microbiology.

Sambrook, J., Fritsch, E. F. \& Maniatis, T. (1989). Molecular Cloning: a Laboratory Manual, 2nd edn. Cold Spring Harbor, NY: Cold Spring Harbor Laboratory.
Stackebrandt, E., Liesack, W. \& Goebel, B. M. (1993). Bacterial diversity in a soil sample from a subtropical Australian environment as determined by $16 \mathrm{~S} \mathrm{rDNA}$ analysis. FASEB $J \mathbf{7}$, 232-236.

Stackebrandt, E., Rainey, F. A. \& Ward-Rainey, N. L. (1997). Proposal for a hierarchic classification system, Actinobacteria classis nov. Int J Syst Bacteriol 47, 479-491.

Stienstra, A. W., Klein Gunnewiek, P. \& Laanbroek, H. J. (1994). Repression of nitrification in soils under climax grassland vegetation. FEMS Microbiol Ecol 14, 45-52.

Torsvik, V., Goksøyr, J. \& Daae, F. L. (1990). High diversity in DNA of soil bacteria. Appl Environ Microbiol 56, 782-787.

Ueda, T., Suga, Y. \& Matsuguchi, T. (1995). Molecular phylogenetic analysis of a soil microbial community in a soybean field. Eur J Soil Sci 46, 415-421.

Wagner, R. (1994). The regulation of ribosomal RNA synthesis and bacterial cell growth. Arch Microbiol 161, 100-106.

Weisburg, W. G., Barns, S. M., Pelletier, D. A. \& Lane, D. J. (1991). $16 \mathrm{~S}$ ribosomal DNA amplification for phylogenetic study. $J$ Bacteriol 173, 697-703.

Weller, R., Weller, J.W. \& Ward, D. M. (1991). $16 \mathrm{~S}$ rRNA sequences of uncultivated hot spring cyanobacterial mat inhabitants retrieved as randomly primed complementary DNA. Appl Environ Microbiol 57, 1146-1151.

Received 13 March 1997; revised 27 May 1997; accepted 3 June 1997. 